\title{
THE CONVENTION ON THE RIGHTS OF PERSONS WITH DISABILITIES UN: ANALYSIS OF THE IMPLEMENTATION IN ANDALUCÍA (SPAIN) OF ARTICLE 33
}

\author{
LA CONVENCIÓN SOBRE LOS DERECHOS DE LAS PERSONAS CON DISCAPACIDAD \\ DE LA ONU: ANÁLISIS DE LA APLICACIÓN DEL ARTÍCULO 33 EN ANDALUCÍA

\section{Marco Garrido-Cumbrera ${ }^{1}$, Jorge Chacón-García ${ }^{2}$, Olta Braçe ${ }^{3}$ y Johannes Schädler ${ }^{4}$}

\begin{abstract}
The United Nations Convention on the Rights of Persons with Disabilities is a major human rights instrument of the United Nations with the goal of ensuring protection of rights of persons with disabilities. In Article 33, 'National implementation and monitoring' establishes, among other things, that States Parties shall implement the Convention and establish or designate a coordination mechanism at government level. This article aims to show the results of implementing Article 33 in Andalucía (Spain) in the context of the European project 'Planning Inclusive Communities' led by the University of Siegen (Germany). The methodology used in this study was based on a comparative analysis of data obtained through a series of surveys addressed to local governments in different European regions. This article shows the results obtained in Andalucía region where the Convention is disseminated in various formats, at local levels it shows a low presence, because ratification have neither led to a legal obligation at lower state levels. Local managers showed disregard for the principles of the Convention and its practical application. This lack of information at local level influences the methods that Spanish occupational therapists (OT) use with persons with disabilities in occupational centers (OC).
\end{abstract}

\section{Keywords:}

persons with disabilities, UN Convention, policy implementation, Article 33, Andalucía, Spain.

1 Doctor in Department of Physical Geography and Regional Geographic Analysis, University of Sevilla, Spain. He has worked in various public health projects and has worked in the World Health Organization (WHO). Email: mcumbrera@us.es

2 Economist - Master of Applied Economic Consulting and Analysis at the University of Sevilla, Spain. He is currently beginning his doctoral thesis on labor market and lifestyles. Email: jorge.chacon.garcia@gmail.com.

3 Expert in urban morphology, public health and law. She has developed her doctoral thesis on the impact of the scatter in the lifestyle and health of the population at the University of Sevilla, Spain. Email: obrace@yahoo.es.

4 Managing director of the Centre for Planning and Evaluation of Social Services (ZPE) at the University of Siegen. He is an educational scientist and university lecturer in Social Work with a focus on rehabilitation and disability services. He has coordinated the project 'Planning Inclusive Communities: Challenges and Strategies of Local Implementation of the UN Convention on Rights of Persons with Disabilities (UNCRPD)'. Email: schaedler@zpe.uni-siegen.de. 


\section{Resumen}

La Convención de las Naciones Unidas sobre los Derechos de las Personas con Discapacidad es un importante instrumento de derechos humanos que tiene como objetivo garantizar la protección de los derechos de las personas con discapacidad. En el artículo 33, 'Aplicación y seguimiento nacional' se establece, entre otras cosas, que los Estados deben aplicar los artículos de la Convención y establecer o designar un mecanismo de coordinación a nivel gubernamental. Este artículo tiene como objetivo mostrar los resultados obtenidos en Andalucía (España) de la aplicación del artículo 33 dentro del proyecto europeo 'Planning Inclusive Communities' dirigido por la Universidad de Siegen (Alemania). La metodología seguida en este estudio se basó en un análisis comparativo de los datos obtenidos a través de una serie de encuestas dirigidas a gobiernos locales de diferentes regiones europeas. Este artículo muestra los resultados obtenidos en la región de Andalucía, en la cual la Convención se difunde en una gran variedad de formas. A nivel local, la Convención se muestra con una presencia baja debido a que la ratificación no ha conllevado una obligación legal en los niveles administrativos más bajos. Los gerentes locales mostraron un cierto desconocimiento de los principios de la Convención de las Naciones Unidas y su aplicación práctica. Esta falta de información a nivel local influye en los métodos que los terapeutas ocupacionales (TO) españoles utilizan con las personas con discapacidad en los centros ocupacionales (CO).

\section{Palabras clave:}

personas con discapacidad, Convención de las Naciones Unidas, implementación de políticas, Artículo 33, Andalucía, España.

Fecha de recepción: 19/07/2016.

Fecha de aceptación: 27/10/2016.

\section{INTRODUCTION}

The Convention on the Rights of Persons with Disabilities is a major human rights instrument United Nations (UN) to protect the rights of persons with disabilities (United Nations, 2006). This UN instrument adopts a modern social model that explicitly recognizes the legal rights of the world's largest marginalized group. Significantly, the Convention marks a shift in thinking about disability from a medical, charitable, or social welfare concern to a human rights issue (Sinecka, 2009). Human and legal rights are essential components of quality of life and equality (Verdugo, Navas, Gómez \& Schalock, 2012).

The Convention is the result of a long process in which various actors were involved: UN Member States, UN observers, national human rights institutions and Non-Governmental Organizations (Guernsey, Nicoli \& Ninio, 2007). The Convention aims at empowering persons with disabilities by granting them a number of civil and political as well as economic, social and cultural rights (Harnacke, 2013). Internationally, this new instrument has had positive consequences for persons with disabilities, highlighting the increased visibility of this group within the system of protection of human rights of the United Nations (Mladenov, 2012).

When it comes to implementation, the most important articles of the Convention are those that are res- ponsible for regulating and monitoring implementation of the Convention itself and building institutions for protection of human rights of persons with disabilities. Specifically, Article 33 'National implementation and monitoring' establishes that States Parties shall give due consideration to establishment or designation of an independent mechanism to promote, protect and monitor implementation of the Convention in different sectors and at different levels and, in accordance with their system of organization, designation of one or more focal points within government for matters relating to implementation of the Convention. Civil society, in particular persons with disabilities and their representative organizations, shall be involved and participate fully in the monitoring process (United Nations, 2006).

At the global level, the highest political and administrative efforts regarding Convention implementation have focused on Articles 33-39, which address creation of mechanisms and institutions for support of policies aimed at improving inclusion of persons with disabilities as well as the creation of monitoring measures for better coordination. Among these, Article 33 of the Convention is based on development of direct actions that are more institutionally oriented and easier to develop than are the mandates of the other articles (Álvarez-Ramírez, 2013). The duty to implement the Convention falls to all government levels of the countries that have ratified. 
It became evident, that implementation of the Convention needs a multi-level approach, in which European, national and regional actors have clear responsibilities. The implementation of the Convention on the local level is in some countries mirrored within a comprehensive disability political action plan, while in other countries selective actions are more common. In countries in which a rights based approach is common (particularly in Nordic countries) formally constituted participation structures such as Disability Councils are the norm, while in other countries with a more charity or medically based tradition of disability politics (like France, Portugal, Spain) the cooperation is more informal (Greve, 2009).

In Spain the Convention has a direct impact on methods and actions carried out at occupational centers (OC). These centers, where occupational therapists (OT) work, provide social services for persons with disabilities. Its aim is to achieve the highest level of skills and abilities development of persons with disabilities (Castresana, 2001).

These centers are managed by local and regional governments, which must establish the program of action to persons with disabilities within the existing legal framework. This legal framework applies according to the monitoring mechanisms established by the national government (Article 33).

\section{Implementation of Article 33 of the Convention in Spain at National level}

The Spanish Government signed the Convention and the Optional Protocol on 30 March 2007 and ratified it (including the Optional Protocol) on 3 December 2007 (United Nations Enable, 2014). Furthermore, Spain committed to develop the 50 articles of the Convention within its own legal system on 3 May 2008 and became one of the first countries to submit its initial State report on implementation of the Convention to the Committee on 3 May 2010 (Brehmer-Rinderer, Zigrovic, Naue \& Weber, 2013).

The Spanish government has fulfilled the first paragraph of Article 33 by Royal Decree 1468/2007, of 2 November 2007 designating the National Council on Disability as a reference body for promotion and monitoring of international legal instruments for human rights of persons with disabilities, and in parti- cular for implementation of the Convention (Cabra de Luna, 2006). The National Council on Disability is an inter-ministerial advisory body through which the organizations representing persons with disabilities and their families participate in planning, monitoring and assessment of policies developed in the disability field (Ministry of Health, Social Services and Equality, 2012). To comply with implementation of the provisions of Article 33, in September 2009 the government of Spain appointed CERMI (The Spanish Committee of Representatives of People with Disabilities), as the independent monitoring body to promote, protect and oversee application of the Convention (CERMI, 2011). The CERMI is the platform for representation, advocacy and action of Spanish citizens with disabilities, representing more than 7,000 organizations and more than 3.8 million persons with disabilities, plus their families, through the organizations in which they are grouped to advance the recognition of their rights and achieve full citizenship with equal rights and opportunities with the remaining of society (CERMI, 2015). This institution participated in the development of the Report on the Implementation of the Convention in Spain (OHCHR Regional Office for Europe, 2011).

In accordance with Article 33.2, the State Party is responsible for creating independent mechanisms to promote, protect and monitor implementation of the Convention as well as other decision-making processes concerning issues relating to persons with disabilities (United Nations, 2006). The Spanish parliament approved in November 2011 the Spanish Disability Strategy 2012-2020, which took into account and elaborated the principal areas of concern and the recommendations made by the Committee on the Rights of Persons with Disabilities, as well as the general targets established in Europe 2020 and the specifics of the European Disability Strategy 2010-2020. In general, the European Disability Strategy focuses on promoting implementation of the Convention (Phillips, 2011). However, ratification and commitment have not yet led to a legal obligation for lower state levels to have formal responsibility for implementation and monitoring of the Convention (Schädler \& Rohrmann, 2013). The monitoring of the implementation of this strategy is carried out by the National Council on Disability, which meets annually with representatives of the regional governments and associations to assess the results of the measurements taken each year. 


\section{Implementation of Article 33 at regional and local level}

The Spanish territory is divided into 17 regions (called Autonomous Communities), 50 Provinces and more than 8,000 Municipalities. The devolution of health and social services to the 17 Autonomous Communities in Spain, which was completed in 1991, led to the development of different care policies in every Autonomous Community, making description of the current national reality with regard to health and social services a difficult task (López-Casasnovas, Costa-Font \& Planas, 2005).

Autonomous Community governments are responsible for providing the local governments with the needed mechanisms and instruments for monitoring and supporting measures to provide care for persons with disabilities. It is clear, however, that there are important inequalities among the Autonomous Communities in terms of dissemination of the Convention principles (CERMI Spanish Delegation for the UN Convention 2012). Each Autonomous Community has its own government and administration, full autonomy in social and health services, and various degrees of autonomy with other institutions such as the criminal justice and education systems. Therefore, there exist important differences in relation to planning and management of disability services among the various Autonomous Communities (Department of Economics Research Services, 2011). In practice, Spain's administration works as a federal state although the background is different. This devolution process followed a different pace in every Autonomous Community depending on regional policy and the model of administration transfer from the central government. However, this devolution process has not been accompanied by a parallel development of national agencies or efficient inter-regional coordination systems (Department of Economics Research Services, 2011). Decisions as to what disability services to make available are now determined regionally, subject to some loose coordination and agreement with the $\mathrm{Na}$ tional Council on Disability. Currently there is no national information system on service provision, planning or financing for either social or health services. This situation has been defined as being especially chaotic in terms of territorial power sharing (García-Armesto, Abadía-Taira, Durán, Hernández-Quevedo \& BernalDelgado, 2010).

Other key instruments for understanding implementation of the Convention within the Autonomous Com- munities are the Regional Action Plans for Persons with Disabilities (Ministry of Health, Social Services and Equality, 2012). Each Autonomous Community has individually and independently developed its own Action Plan for Persons with Disabilities, including the principles of the Convention unevenly. This makes the assessment of implementation of the Convention in Spain even more complex (Cordero-Gordillo, 2011).

While at the national and regional levels the Convention has been disseminated in different formats, at the local level the Convention shows low presence (United Nations, 2010). In the case of Spain, the municipalities are responsible for developing care programs for persons with disabilities.

\section{MetHOD}

During 2013 and 2014, the European research project 'Planning Inclusive Communities' was done to assess implementation of Article 33 of the Convention at the local level in selected European Countries (including Spain) that had signed the Convention. This project was coordinated by the Centre for Planning and Evaluation of Social Services at University of Siegen and was funded by the regional government of North RhineWestphalia (Germany) (Schädler et al., 2013).

The research project focuses on the implementation of the Convention by local governments. The project contains a regional analysis of social planning activities related to Convention in 10 selected European regions. The overall aim is to develop a typology of local planning and implementation strategies and the identification of examples of good planning practice towards inclusive communities (Rohrmann, Schädler, Kempf, Konieczny \& Windisch, 2014).

In this project, Rohrmann et al. (2014) developed a questionnaire of 44 questions aimed at local social services managers. These questions are grouped into different sections. Specifically a section was intended to determine the degree of knowledge about the mechanism to promote, protect and monitor the Convention (Article 33) implementation.

In Spain, the Autonomous Community of Andalucía was chosen as a participant region because of its demographic and economic characteristics. Researchers, using the questionnaire, interviewed local personnel responsible for management and planning for persons with disabilities in seven municipalities. These munici- 
palities, with more than 20,000 inhabitants and located within of Andalucía, are responsible for provision of care and social services and for development of local programs targeted at persons with disabilities (Consejería para la Igualdad y Bienestar Social, 2011).

\section{RESULTS}

In this study we show the results obtained on the degree of awareness of the Convention and Article 33 at local level in Andalucía. Specifically the local managers and planners had little knowledge of the rules of the Convention and its impact on legislation. The main documents for local governments managers were the quality guidelines for services at local level (85.7\%) and recommendations of disability organizations (71.4\%). While the Convention was the least relevant document (14.3\%) (Figure 1).

The results in figure 1 show that in a territorial organization as disaggregated as Spanish state, the articles of the Convention do not become known at the local level, at least in the Autonomous Community of Andalucía.

This study showed that part of the responsibility for disability policy is concentrated at the local level. Although the biggest problem is that currently there are not formulas for transmission of Convention principles from the state and/or regional level to the local level, nor is there any coercive legislation or mandate requiring local governments to implement these principles.

Figure 1:

Most relevant recommendations and legal prescriptions for activities aimed towards the inclusion of persons with disabilities at local level in Andalucía.

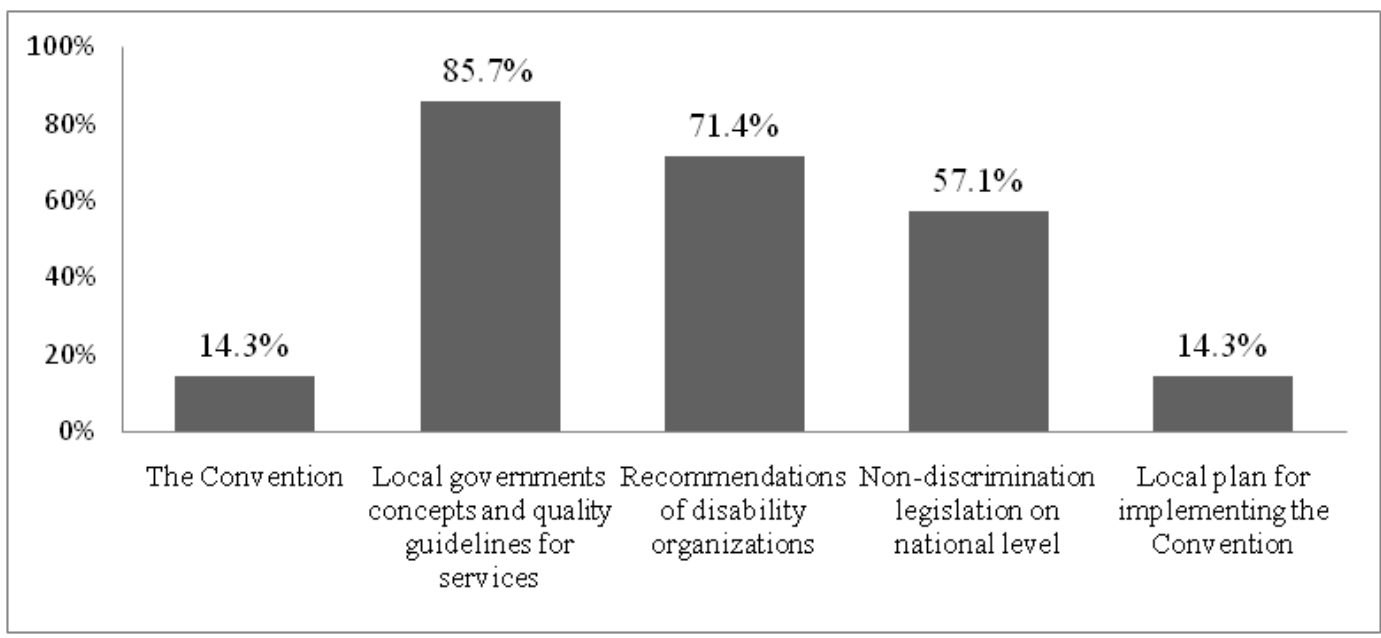

Source: Own elaboration with dates of Planning Inclusive Communities project

\section{DisCUSSION}

Spain was the first State to submit its initial report to the Committee on the Rights of Persons with Disabilities (CRPD). Based on this report from Spain, the October 192011 the Committee prepared a document for Spain called "Consideration of reports submitted by States parties under article 35 of the Convention" where described the positive aspects and the principal areas of concern and recommendations about the Convention articles implementation in Spain (CRPD, 2011). In this report on Spain no reference is made to article 33 "National implementation and monitoring" and the difficulties found for its implementation in Spain. There are references to various articles such as to article 31 , where the Committee highlighted the low level of disaggregated data to understand the situations of specific groups of persons with disabilities for developing 
laws, policies and programs adapted to their situations; and assessing the implementation of the Convention. Moreover, the Committee requests to the government of Spain to implement these recommendations among the Government and Parliament, relevant Ministries, and members of relevant professional groups, as well as to local authorities. As we have demonstrated in this study, due to the devolution process, the regional and local levels have attributed more competences on disabilities than the national powers (CRPD, 2011).

In 2013 it was approved the General Law on Rights of Persons with Disabilities and their Social Inclusion recognizes persons with disabilities as holders of a series of rights and public authorities as guarantors of the real and effective exercise of those rights under approved with the provisions of the Convention. And it establishes the system of offenses and penalties that guarantee the basic conditions on equal opportunities, non-discrimination and universal accessibility for persons with disabilities.

Implementation of policy and legislation centered on persons with disabilities in Spain has always presented problems when it comes to measurement, quantification and assessment of the results.

Specifically, the Convention principles, included within the national legislation, have not been implemented uniformly throughout the entire national territory because of the mentioned political-administrative division of the Spanish state. Therefore, the articles of the Convention have not reached the same levels of implementation in all the Spanish Autonomous Communities and local territories (Pérez Bueno \& Álvarez Ramírez, 2013).

This administrative organization has allowed each Autonomous Community to develop independently its own Disability Policy and Action Plan without any surveillance or monitoring by the national authority based in Madrid, and even make their own plans for implementation of the Convention (Ministry of Health, Social Services and Equality, 2012).

The complexity of this system has resulted in creation of a set of national, regional and local laws and plans with little coordination between them. As a result, the Convention principles have not been fully and equally transmitted and disseminated from the national to the regional and local levels. Therefore, there is hegemony of the national legislation, which eclipses the knowledge and dissemination of the Convention among local managers and planners. According to the study at local level, mentioned before, the intensity of reception of the Convention on municipal level in Andalucía is rather low or there is little knowledge at the side of relevant local actors.
Law's system complexity and the lack of a common supervisory mechanism (Article 33) directly influence actions management aimed at persons with disabilities. Specifically at each local OC the organization is different and legal framework implementation varies from one municipality to another (López-Pino \& Seco-Martón, 2005). This has a direct impact on the services provided by each OT on the OC.

In Spain, OT work is led by each OC internal procedures, which are based on local government guidelines. Therefore, each OC offer a different service.

The OT is a key figure in the social and labor development of persons with disabilities. Therefore, the lack of mechanisms for monitoring the OC services has caused that persons with disabilities from each Autonomous Community has a different of social, labor and education development degree (Garrido-Cumbrera \& Chacón-García, 2016).

This study demonstrates the lack of monitoring mechanisms by the central and regional governments to ensure and assess implementation of the Convention principles at the local level. Another important issue at the local level is the Mediterranean model predominant in Spain: the limited social transfers and benefits to this level from the national and regional levels are partly compensated by the strong supporting role of families and associations. Therefore, disability-specific issues at the local level are mainly addressed outside the administrative structure by family members or by disability organizations.

\section{CONCLUSION}

Despite approval and ratification of the Convention by Spain in 2007, the considerable devolution of disability management and planning to the Autonomous Communities makes its implementation tremendously disparate. At the local level, the municipalities' respondents based their decisions on regional or local laws, showing ignorance about the Convention itself and its signature and ratification by Spain, because international agreements are far removed from local activity. At the local level the Convention is unknown, making it impossible to establish policies for persons with disabilities in common. Each of the 17 Autonomous Communities sets its priorities and each of the 8,000 municipalities established which such regional priorities are more priority for them. Therefore, Spain must improve coordination between social services and health services, the communication be- 
tween the different administrations (central government, Autonomous Communities and local governments) and inequalities between the different territories.

These inequalities between territories directly influence on the OC and the work developed by OT. The lacks of common mechanisms cause inequalities in the services offered by OT to persons with disabilities in each municipality or region of Spain.

To improve this situation, it would be necessary that the agencies existent for ensuring compliance and implementation of the Convention principles are better coordinated at different geographic levels and use a better monitoring system. In fact, article 31 'Statistics and data collection' mentions that should be collected disaggregated information to assess the implementation of the Convention' obligations. In recent years, Swedish government has improved levels of coordination and monitoring of the Convention principles by using a toolbox with checklists for municipalities to report on the implementation of the Convention in this country. This checklist has a list of relevant criteria for reporting and to initiate a dynamic development both in local regions but also among municipalities by establishing a cross-national ranking list where can be known the level of implementation of each action plan (Linden, 2013).

This situation analyzed in Andalucía (Spain) can be transferred to other countries decentralized where the regional imbalances are important and where the administrative levels related to social and disability issues have an important level of decentralization.

\section{ACKNOWLEDGEMENTS}

The authors thank Professor Mark Bierner for reviewing and editing the manuscript.

This research was part of the research project "Planning Inclusive Communities" (KST: 4012004200 201116 - MAIS NRW) funded by the Länder NorthRhin-Westfalia (Germany).

\section{REFERENCES}

Álvarez-Ramírez, G. (2013). Discapacidad y sistemas alternativos de resolución de conflictos. Un cauce adicional de acceso a la justicia y una oportunidad para la inclusión [Disability and alternative conflictre solution systems. An additional channel of justice access and opportunity for inclusion]. Madrid: CERMI. Retrieved from http://www.feafes.org/publicaciones/Discapacidadsistemasalternativosconflictos.pdf.

Brehmer-Rinderer, B., Zigrovic, L., Naue, U., \& Weber, G. (2013). Promoting health of persons with intellectual disabilities using the UN Convention on the Rights of Persons with Disabilities: early implementation assessment in Spain and Hungary. Journal of Policy and Practice in Intellectual Disabilities, 10(1), 25-36. doi: 10.1111/ jppi.12018.

Cabra de Luna, M.A. (2006). Dimensión y alcance de las políticas públicas sobre discapacidad en España: el reparto de papeles entre el estado y las CCAA[Size and scope of public policy on disability in Spain: the role distribution between the State and the Autonomous Communities]. Revista del Ministerio de Trabajo y Asuntos Sociales [Journal of the Ministry of Labor and Social Affairs]. Retrieved from http://www.empleo.gob.es/es/publica/pub_electronicas/destacadas/Revista/numeros/65/Est05.pdf

Castresana, H. (2001). El proceso de mejora en un Centro Ocupacional („Una práctica de investigación-acción“) [The process of improvement in Occupational Center („,A practical action research“)]. Siglo Cero: Revista Española sobre Discapacidad Intelectual, 32(197), 15-34.

CERMI Spanish Delegation for the UN Convention. (2012). Derechos Humanos y Discapacidad Informe España 2012[Spanish Report on Human Rights and Disability 2012], Madrid: CERMI.

Consejería para la Igualdad y Bienestar Social. (2011). II Plan de Acción Integral para las Personas con Discapacidad en Andalucía 20112013 [II Integral Plan of Action for Persons with Disabilities in Andalusia 2011-2013]. Sevilla, Spain: Junta de Andalucía.

Committee on the Rights of Persons with Disabilities (CRPD). (2011). Concluding observations of the Committee on the Rights of Persons with Disabilities. New York: United Nations. http://tbinternet.ohchr.org/_layouts/treatybodyexternal/Download.aspx?symbolno=CRPD/C/ESP/CO/1\&Lang=En

Convention on the Rights of Persons with Disabilities (UNCRPD) 2016. Retrieved March 15, 2015 from United Nations website, http:// www.un.org/disabilities/convention/conventionfull.shtml

Cordero-Gordillo, V. (2011). El fomento del empleo de las personas con discapacidad por las Comunidades Autónomas. In Los nuevos marcos de relaciones laborales en el renovado estado de las autonomías: XXI Congreso Nacional de Derecho del Trabajo y de la Seguridad Social (pp. 253-270). Tirant lo Blanch.

Department of Economics Research Services. (2011). El traspaso de competencias en el sector público [Thedevolutionprocess in thepublic sector]. Madrid: Confederación Española de Organizaciones Empresariales [Spanish Confederation of Employers' Organizations]. Retrieved from http://www.ceoe.es/resources/image/informe_traspaso_competencias_sector_publico_diciembre_2011.pdf

García-Armesto, S., Abadía-Taira, M.B., Durán, A., Hernández-Quevedo, C., \& Bernal-Delgado, E. (2010). Spain: Health System Review. 
Health Systems in Transition. 12 (4): 1-295. Retrieved from http:// www.euro.who.int/__data/assets/pdf_file/0004/128830/e94549. pdf

Garrido-Cumbrera, M., \& Chacón-García, J. (2016). Atlas Laboral de las Personas con Discapacidad 2016 [Labor Atlas for Persons with Disabilities 2016]. Barcelona: Bosch.

Guernsey, K., Nicoli, M., \& Ninio, A. (2007). Convention on the Rights of Persons with Disabilities. Washington, DC: The World Bank. Retrieved from http://siteresources.worldbank.org/SOCIALPROTECTION/Resources/SP-Discussion-papers/Disability-DP/0712.pdf

Harnacke, C. (2013). Disability and capability: exploring the usefulness of Martha Nussbaum's capabilities approach for the UN Disability Rights Convention. Journal of Law Medicine \& Ethics, 41(4), 768780. doi: 10.1111/jlme.12088.

Ley 27/2013, Diciembre 27, de racionalización y sostenibilidad de la administración local [Law 27/2013, December 27, rationalization and sustainability of local government]. Boletín Oficial del Estado [Official Spanish Gazette], December 30, number 312 2013, pp.106468-106473. Retrieved from January 2015 http://www.boe. es/diario_boe/txt.php?id=BOE-A-2013-13756

Linden, A. (2013). Handisam-Checklist, Workshop Planning Inclusive Communities, University of Siegen. Siegen: Zentrum für Planung und Evaluation Sozialer Dienste (ZPE).

López-Casasnovas, G., Costa-Font, J., \& Planas, I. (2005). Diversity and regional inequalities in the Spanish 'system of health care services. Health Economics, 14(S1), S221-S235. doi: 10.1002/hec.1038.

López-Pino, C. M., \& Seco-Martón, E. (2005). Discapacidad y empleo en España: su visibilidad [Disability and Employment in Spain: its visibility]. Revista Innovar Journal Revista de Ciencias Administrativas y Sociales, 15(26), 59-72.

Ministry of Health, Social Services and Equality. (2012). Spanish Disability Strategy 2012-2020, Policy document. Madrid: Ministry of Health, Social Services and Equality of Spain.

Mladenov, T. (2012). The UN Convention on the Rights of Persons with Disabilities and its Interpretation. ALTER. European Journal of Disability Research, 7(1), 69-82. doi: 10.1016/j.alter.2012.08.010.

National Disability] Boletín Oficial del Estado [Official Spanish Gazette], December 4, number 311 2013, pp.110403-110412. Retrieved from http://www.boe.es/boe/dias/2009/12/26/pdfs/BOEA-2009-20890.pdf

OHCHR Regional Office for Europe. (2011). Study on the implementation of Article 33 of the UN Convention on the Rights of Persons with Disabilities in Europe. Brussels: OHCHR Regional Office for Europe. Retrieved from http://europe.ohchr.org/Documents/Publications/Art_33_CRPD_study.pdf

Pérez Bueno, L. C., \& Álvarez Ramírez, G. (2013). 2003-2012: 10 años de legislación sobre no discriminación de personas con discapacidad en España [2003-2012: 10 years of legislation on non-discrimination of people with disabilities in Spain]. Madrid,Spain: CERMI.
Phillips, S.D. (2011). EU Disability Policy and Implications of EU Accession for Disability Rights in Education and Employment in Bulgaria, Romania, Croatia, and the Former Yugoslav Republic of Macedonia. Journal of Disability Policy Studies, 22(4), 208-219. doi: $10.1177 / 1044207311414710$.

Real Decreto 1855/2009, de 4 de diciembre, por el que se regula el ConsejoNacional de la Discapacidad [Royal Decree 1855/2009, of 4 December, by which regulates the Council

Rohrmann, A., Schädler, J., Kempf, M., Konieczny, E., \& Windisch, M. (2014). Inklusive Gemeinwesen Planen [Planning Inclusive Communities]. Düsseldorf, Germany: MAIS. Retrieved from https:// www.uni-siegen.de/zpe/projekte/inklusivegemeinwesen/inkluplan-abschlussbericht_februar_2014_ii.pdf

Schädler, J., \& Rohrmann, A. (2013). Summary of the Exploratory Study on Implementation of UN-CRPD in Local Governments in Selected European Countries. Siegen: University of Siegen.

Sinecka, J. (2009). The Czech Republic: Report on the current state of disability law and policy. Journal of Disability Policy Studies, 19(4), 195-203. doi: 10.1177/1044207308314947.

Spanish Committee of Representatives of People with Disabilities (CERMI). (2015). What is the CERMI? [¿Quées el CERMI?]. Madrid: CERMI.

Spanish Committee of Representatives of People with Disabilities (CERMI). (2011). Human Rights and Disability. Alternative Report Spain 2010 by the Comité Español de Representantes de Personas con Discapacidad [Spanish Committee of Representatives of People with Disabilities]. Madrid: CERMI.

United Nations Enable. (2014). Development and human rights for all. New York, NY: United Nations.

United Nations. (2010). Vigilancia del cumplimiento de la Convenciónsobre los Derechos de las Personas con Discapacidad[Compliance and surveillance of the Convention on the Rights of Persons with Disabilities]. New York, NY: United Nations.

Verdugo, M.A., Navas, P., Gómez, L.E., \& Schalock, R.L. (2012). The concept of quality of life and its role in enhancing human rights in the field of intellectual disability. Journal of Intellectual Disability Research, 56(11), 1036-1045. doi: 10.1111/j.1365-2788.2012.01585.x. 